\title{
DINAMICA NUMĂRULUI ȘI STRUCTURII POPULAȚIEI DIN MUN. CHIȘINĂU ÎN PERIOADA INTERCENSITẢRĂ
}

\author{
Vitalie ŞTÎRBA ${ }^{\oplus}$, cercetător științific, \\ Centrul de Cercetări Demografice al INCE, Republica Moldova \\ DOI: https://doi.org/10.36004/nier.cdr.2019.14-18
}

JEL Classification: J110.

In contextul situației demografice din Republica Moldova, când se evidențiază reducerea numărului populației, accentuată prin creșterea gradului de îmbătrânire și depopularea unor localități, mun. Chișinău înregistrează o creștere ușoară a numărului de rezidenți, în același timp menținând o structură a populației relativ tânără. Creșterea numărului populației a derivat din mișcarea naturală pozitivă, dar și a sporului migrației interne. Ponderea considerabilă a populației de vârstă fertilăa, în decursul perioadei analizate, a asigurat un număr anual de 6,4-8,0 mii nașteri, ceea ce depășsște numărul anual de decese cu circa 0,5-1,8 mii. Recensămintele din 2004 și 2014 au evidențiat în mun. Chișinău prezența fenomenului migrației internaționale, în care locuitorii suburbiilor sunt implicați în mai mare măsură. În perioada anilor 2011-2016, sporul migrației interne din mun. Chișinău a asigurat o creștere a numărului populației cu circa 4,1-5,9 mii persoane, preponderent în grupele de vârstă 20-39 ani. Afluxul migranților interni are un rol de compensare a pierderilor în urma implicării locuitorilor mun. Chișinău în migrația internațională. Având în vedere situația curentă, evoluția situației demorafice din mun. Chişinău va evidenția creșterea gradului de îmbătrânire a populației, dar și descreșterea sporului migrației interne.

Cuvinte-cheie: municipiul Chișinău, structura populației, dinamica populației, migrația internă, îmbătrânirea populației.

In the context of the demographic situation in the Republic of Moldova, when the reduction of the number of the population is emphasized, accentuated by population ageing and depopulation of some localities, Chisinau municipality registers a slight increase of the number of residents, at the same time maintaining a relatively young population structure. The increase in population is due to natural population growth, as well as a positive balance of internal migration. The considerable share of the young and reproductive active population, during the analysed period, ensured annually between 6.4 and 8.0 thousand births, which exceeds the annual number of deaths by about 0.5-1.8 thousand. The 2004 and 2014 population censuses revealed presence of phenomenon of international migration in Chisinau in which are involved rather residents of suburbs. Between 2011 and 2016, internal migration has increased the population of the Chisinau municipality by about 4.1-5.9 thousand people, mainly in the age groups 20-39 years. The phenomenon of internal migration has the effect of compensating for the loss of population of the Chisinau municipality due to involvment in international migration. Taking into account the current population structure, the further evolution of the demographic situation in Chisinau municipality will highlight the population aging, but also the reduction of the intensity of internal migration.

Key words: Chisinau municipality, population structure, population dynamics, internal migration, population aging.

\section{Introducere}

Pe parcursul ultimelor decenii, dinamica populației din Republica Moldova a cunoscut unele schimbări semnificative, în mare măsură fiind supuse transformărilor numărul, structura și distribuția teritorială a populației [1]. Aceasta este urmare a valurilor demografice, care influenţează asupra numărului anual de nașteri și decese, dar și a fenomenului migrației internaționale, care s-a

\footnotetext{
${ }^{\circledR}$ Ştîrba Vitalie, vitalie.stirba@gmail.com
} 
intensificat începând cu mijlocul anilor '90. Tendințele demografice actuale evidențiază o descreștere numerică și îmbătrânirea continuă a populației, iar unele localități, în special rurale, se confruntă cu procesul de depopulare. În același timp, mun. Chișinău își menține numărul populaţiei cu o structură relativ tânără, în mare parte datorită mișcării naturale a populației pozitive și a soldului de migranți interni și internaționali.

Municipiul Chișinău încadrează în componența sa circa 1/4 din numărul total al populației Republicii Moldova, în timp, evidențiind o creștere ușoară, dar constantă, al numărului de rezidenți. Structura populației din mun. Chişinău avantajează un spor natural pozitiv, având în vedere predominarea numărului de nașteri asupra deceselor.

Statutul politico-administrativ și socioeconomic conferă mun. Chișinău un grad sporit de atracție, ceea ce facilitează mișcările migratorii interne. La rândul său, soldul pozitiv al migrației interne are un efect de compensare a pierderii numărului de locuitori implicați în migraţia internațională.

Scopul acestui articol este analiza schimbărilor numărului și structurii populației din mun. Chișinău în perioada intercensitară, precum și a factorilor ce au influențat evoluția distribuției pe vârste și sexe a populației.

\section{Date și metode}

În contextul organizării administrativ-teritoriale, mun. Chișinău este alcătuit din 1 municipiu, 6 orașe și 12 comune, precum și localităţile din componenţa celor enumerate [7].

Datele utilizate cu privire la numărul și distribuția pe vârste a populației, mișcarea naturală și migrația internă / internațională au fost preluate din banca de date al Biroul Național de Statistică și din rezultatele Recensămintelor din 2004 și 2014 [3, 8, 9, 5].

Exercițiul de colectare a datelor statistice privind populația și evenimentele demografice de către BNS are o metodologie specifică, în dependență de furnizorul primar al datelor. Numărul populației stabile din anii calendaristici se referă la rezidenții mun. Chișinău (populația de jure), unde se ține cont de mișcarea naturală și sporul migrației interne, neinclusă fiind migrația internațională nedeclarată.

Recensăminte din 2004 și 2014 disting populația prezentă în momentul de referință (populația de facto). Neacoperirea mun. Chișinău la Recensământul populației din 2014 a fost complementată prin exercițiul de estimare a numărului populației, la baza căruia au fost sursele de date administrative.

Distribuția nașterilor în profil teritorial este efectuată ținându-se cont de viza de reședință a mamei. Cadrul legal, ce determină modalitatea de înregistrare a noi-născuților, poate deteriora calitatea indicatorului, având în vedere termenul de 90 de zile prevăzut pentru solicitarea primului act de stare civilă, dar și a numărului de persoane cu dublă cetățenie [2].

Decesele sunt atribuite unităților administrativ-teritoriale unde persoanele și-au avut ultima reședință.

Datele cu privire la mișcările migratorii interne sunt disponibile începând cu anul 2011 și se referă la momentul înregistrării acestora la Agenţia Servicii Publice.

\section{Rezultate și discuții}

Începând cu mijlocul anilor '90 ai sec. XX, majoritatea unităţilor administrativ-teritoriale din Republica Moldova au cunoscut o descreștere constantă a numărului populației, care, în mare parte, se datora unui spor natural descrescător, dar și intensităţii migrației internaționale [1]. Municipiul Chișinău, prin prisma statutului său administrativ și socioeconomic, a reușit să fie unul dintre polii de atracție a populației, în special tinere, ceea ce a influențat asupra menținerii, dar și creșterii numărului populației $[11,10]$. Astfel, începând cu 2004, numărul populației stabile a mun. Chișinău a cunoscut o creștere de la 775,6 mii persoane în 2004 la 787,1 mii persoane în 2010, 805,9 mii persoane în 2014 și 827,7 mii persoane în 2018 (Fig. 1.). 
Creșterea evidențiată a numărului de rezidenți a putut fi observată în toate localitățile din componența administrativă a municipiului, cel mai mare spor revenind orașului Chișinău. Dinamica populației din localitățile suburbane derivă din conexiunea strânsă dintre acestea și orașul Chișinău, dar și de accesul la un spectru larg de servicii publice și infrastructură, de care populația acestora poate beneficia. Orașele satelite, care au un efectiv al populației relativ mic (între 3,5-20 mii persoane), sunt bine integrate în aglomeraţia urbană și pot fi privite în calitate de sectoare complementare al orașului Chișinău (cu excepția orașului Vadul lui Vodă); ele înregistregistrează o creștere anuală constantă a numărului de rezidenți, însă având în vedere mărimea inițială a acestora, sporul nu este atât de însemnat din punct de vedere numeric.

Comunele atribuite mun. Chișinău au o importanță deosebită în distribuția teritorială a populației și întrunesc în componența sa circa $10 \%$ din numărul total de rezidenți. Pe parcursul perioadei analizate, numărul populației din localitățile rurale din cadrul mun. Chișinău a evidențiat o creștere de la 61,9 mii persoane în 2004 la 69,9 mii persoane în 2010, 74,2 mii persoane în 2014 și 77,2 mii persoane în 2018; respectiv, cu o creștere anuală a numărului populației de $1 \%$. Î̉n contextul unei rețele multiple de comune din cadrul mun. Chișinău, dar și de suprafața pe care acestea se întind, creșterea evidențiată a numărului de rezidenți poate fi caracterizată ca fiind una lentă și nu accentuează intensificarea unui proces de suburbanizare.

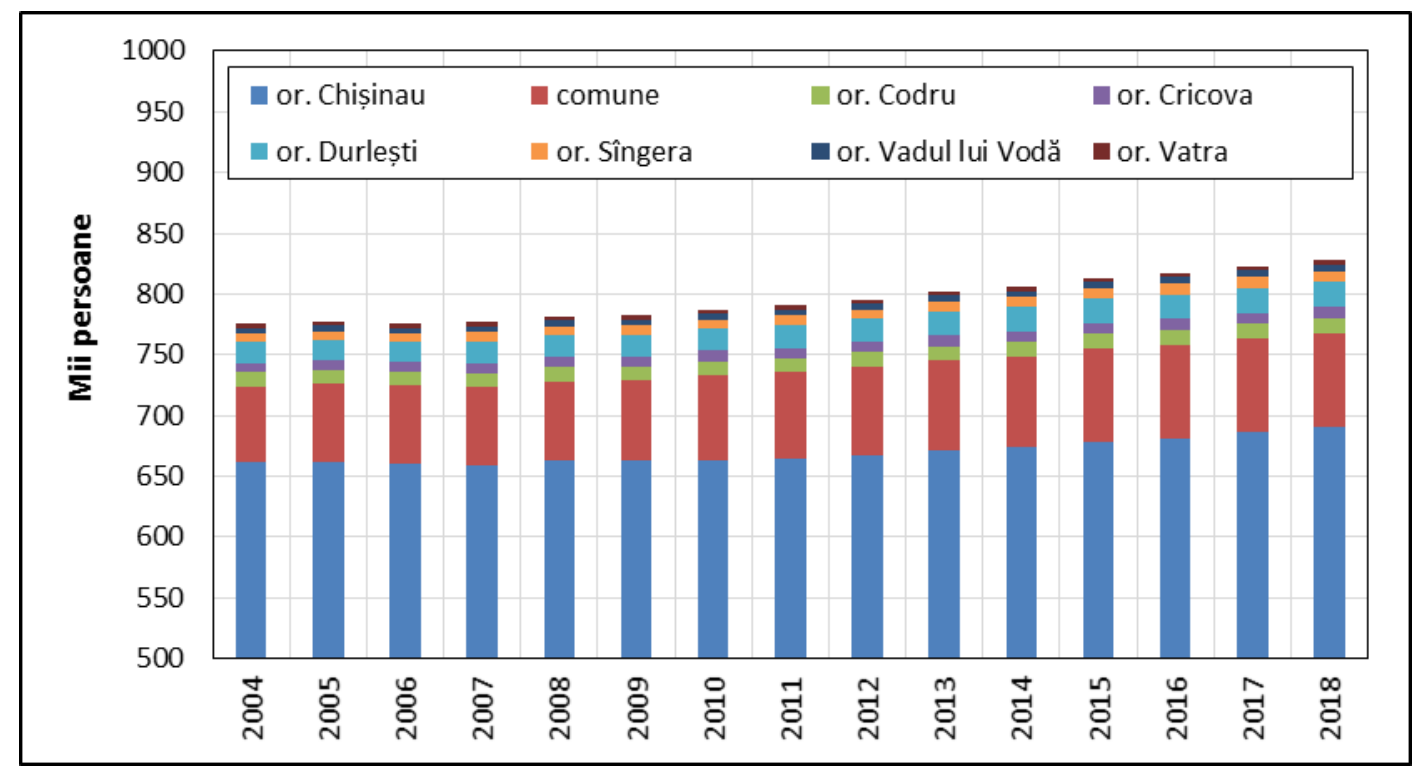

Figura 1. Numărul populației stabile (de jure) din mun. Chișinău la 1 ianuarie, 2004-2018

Sursa: Biroul Național de Statistică

Evoluția structurii pe vârste și sexe a populației mun. Chișinău din perioada intercensitară, în mare parte, este rezultatul mișcării valurilor demografice, ce derivă din mărimea numerică a grupelor de vârste. În același timp, numărul anual de nașteri, decesele din anumite grupe de vârstă, dar și mișcările migratorii interne și internaționale au o influență directă asupra dinamicii distribuției numărului populației pe vârste și sexe.

Recensământul populației din 2004 a evidențiat o predominare numerică a grupelor de vârstă 15-29 și 35-54 ani, care sunt descendenții generațiilor născute între anii 1960-1970 și 19801990 (Fig. 2.). Cohortele menționate, în timp, au fost complementate cumulativ prin intermediul migrației interne, având în vedere gradul de atracție a mun. Chișinău. Întrucât gradul de implicare în migrație la femei şi bărbaţi este diferit (în dependență de motivul schimbării locului de trai: educație, încadrarea în câmpul muncii etc.), în grupurile de vârstă 15-34 ani s-a evidențiat o 
disbalanță numerică în favoarea femeilor. În grupurile de vârstă de peste 45 ani, disbalanța dintre numărul de bărbaţi și femei se accentuează printr-un grad diferit al intensităţii mortalităţii.

Fluctuațiile de îngustare și lărgire a bazei piramidei pe vârste și sexe au derivat din numărul de femei de vârstă reproductivă din anii consecutivi, ceea ce a influențat asupra diferenţelor în numărul de copii din grupele de vârstă 0-15 ani. Predominarea numerică a cohortelor anilor ' 80 a avut o influență asupra numărului de nașteri în perioada intercensitară, ceea ce s-a reflectat asupra mărimii cumulative a grupurilor de vârstă 0-4 și 5-9 ani din 2014.

Intensitatea migrației internaționale din anumite vârste, schimbările din calendarul nașterilor, dar și reducerea lentă a mortalității în vârstele adulte, treptat, influențează asupra nivelării numerice a distribuției populației pe grupurile de vârstă.
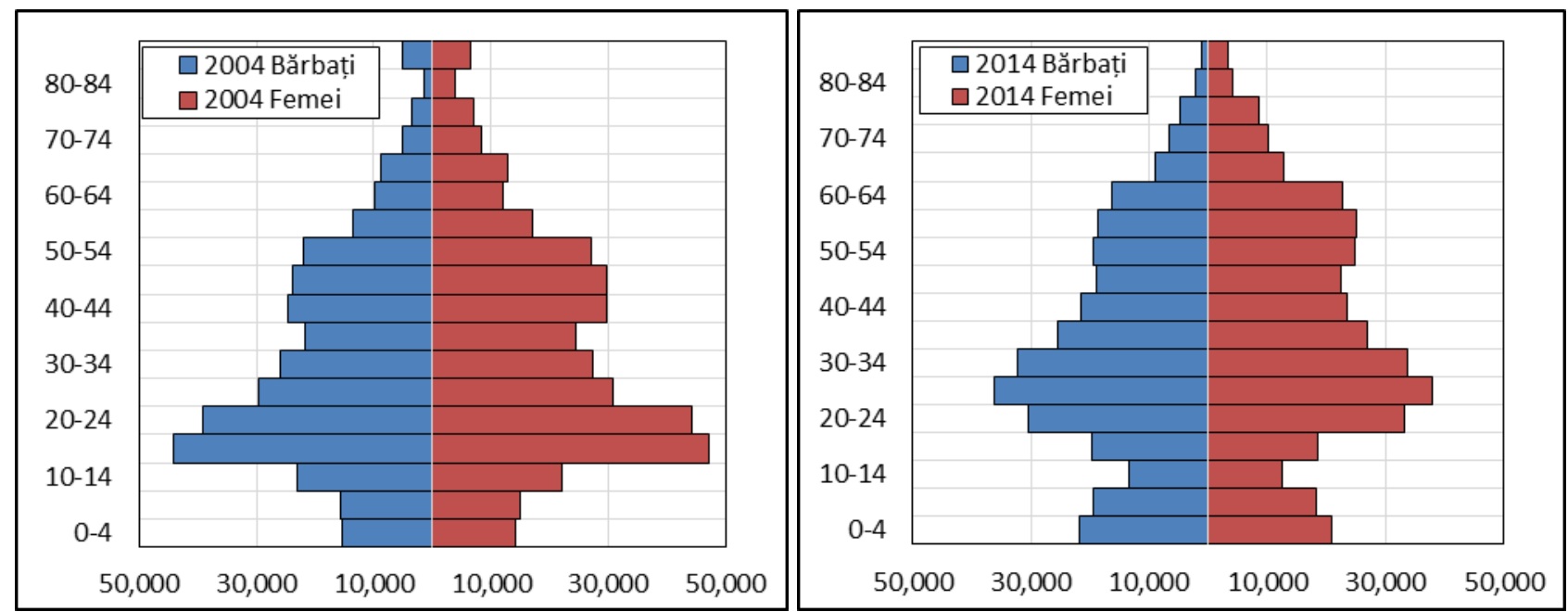

Figura 2. Distribuția populației pe vârste și sexe în mun. Chișinău la recensămintele populației din 2004 și 2014

Sursa: Rezultatele Recensămintelor populației din 2004 și 2014

Distribuția populației în profil teritorial, în dependență de grupurile de vârstă, poartă un caracter neuniform. La Recensământul din 2004 s-a evidențiat o predominare numerică a grupelor de vârstă 15-29 ani, care alcătuiau circa 25-30\% din populația corespunzătoare la nivel de republică. În perioada Recensământului din 2014, cohortele numeroase și-au păstrat ponderea numerică, în același timp fiind evidențiată o creștere numerică a grupelor de vârstă din generațiile tinere (Fig. 3.).

Atât în 2004 cât și în 2014, în mun. Chișinău se observă o predominare a numărului de femei începând cu vârsta de 15 ani, fapt ce accentuează influența migraţiei interne pentru populaţia tânără și în vârstă aptă de muncă, dar și o diferențiere a intensităţii mortalităţii în vârstele înaintate. Totodată, concentrarea unui stoc considerabil al populației de vârstă reproductivă în perioada intercensitară a facilitat sporul numărului de nașteri ce au crescut vădit ponderea grupei de vârstă 09 ani din mun. Chișinău, comparativ cu populația totală de vârstă corespunzătoare. 

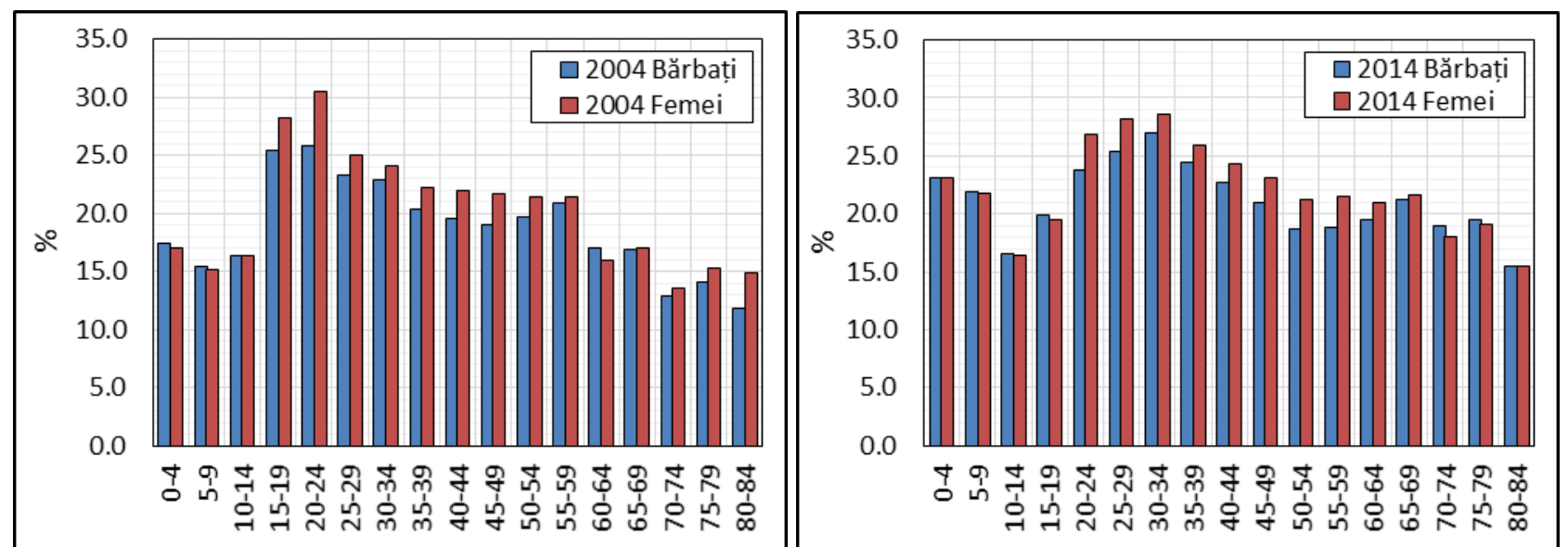

Figura 3. Ponderea rezidenților din Chișinău pe grupe de vârstă din populația Republicii Moldova

Sursa: Calculat în baza rezultatelor Recensămintelor populaţiei din 2004 şi 2014

În contextul intensității sporite a migrației internaționale [12], mun. Chișinău pierde un număr considerabil de locuitori. La Recensămintele din 2004 și 2014, în afara hotarelor țării se aflau 27,4 mii persoane, și, respectiv, 22,2 mii persoane originare din mun. Chișinău, dintre care o proporție considerabilă constituind locuitorii suburbiilor (26\% în 2004 și $40 \%$ în 2014). În contextul Republicii Moldova, putem concluziona că emigrația populației din mun. Chișinău are o intensitate mai redusă.

Populația tânără este în mai mare măsură expusă riscului de a se implica în migrația internațională, iar având în vedere structura tânără a populației din mun. Chișinău, aceste pierderi numerice al efectivului populației sunt semnificative. Emigrarea populației tinere de vârstă reproductivă afectează și numărul anual de nașteri.

O parte considerabilă a emigranților originari din mun. Chișinău sunt implicați în migrația de muncă, inclusiv cea circulară. Oportunitățile de înmatriculare în învățământul superior oferite de statele partenere contribuie la intensificarea migrației educaționale, fapt ce reduce drastic numărul de studenți din sistemul național de învățământ originari din mun. Chișinău, cât și din alte raioane. În acest context, mun. Chişinău pierde potențialii migranți interni, care sunt reorientaţi spre implicarea în migrația internațională.

Tabelul 1. Rezidenții mun. Chișinău aflați în afara țării la Recensămintele populației din 2004 și 2014

\begin{tabular}{|c|c|c|c|c|c|c|c|c|c|}
\hline & 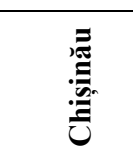 & 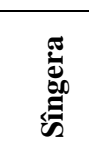 & 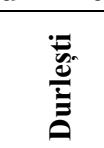 & 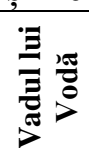 & $\frac{\pi}{\pi}$ & 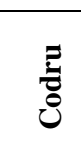 & 苞 & 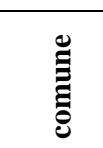 & हूँ \\
\hline RPL 2004 (persoane) & 20258 & 725 & 854 & 340 & 172 & 718 & 562 & 3755 & 27384 \\
\hline RPL 2014 (persoane) & 13099 & 761 & 1138 & 273 & 265 & 992 & 797 & 4829 & 22154 \\
\hline
\end{tabular}

Sursa: Rezultatele Recensămintelor populației din 2004 și 2014

Migrația internă are un rol important în contextul menținerii numărului și structurii tinere a populației din mun. Chișinău [10]. Sporul pozitiv al mișcărilor migratorii interne compensează pierderile populației din mun. Chișinău implicată în migrația internațională. Afluxul de migranți, în mare parte, este asigurat de condițiile mai avantajoase pe care le oferă mun. Chișinău, în special pe segmentele educației, piața muncii mai diversificată, servicii publice și infrastructură.

În perioada 2011-2016, creșterea anuală a numărului populației, ca urmare a mișcărilor migratorii interne, a constituit circa 4,1-5,9 mii persoane. Soldul migrației interne din mun. Chișinău accentuează, printre numărul de sosiți, un spor considerabil în grupele de vârstă 20-39 ani, 
care 1̂și atribuie o pondere de peste $85 \%$ din total. Totodată, soldul migrației interne evidenţiază o discrepanţă numerică între sexe, înregistrând un spor la femei cu 50-85\% mai mare comparativ cu bărbații, ceea ce poate fi explicat printr-un grad diferit de înmatricularea în sistemul de învăţământ superior, dar și o predispoziție mai pronunțată în vederea schimbării localității de reședință.

Tabelul 2. Soldul migrației interne în mun. Chișinău, 2011-2016

\begin{tabular}{|c|c|c|c|c|c|c|c|c|c|c|c|c|}
\hline & \multicolumn{2}{|c|}{2011} & \multicolumn{2}{|c|}{2012} & \multicolumn{2}{|c|}{2013} & \multicolumn{2}{|c|}{2014} & \multicolumn{2}{|c|}{2015} & \multicolumn{2}{|c|}{2016} \\
\hline & 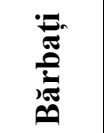 & 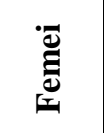 & 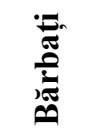 & 离 & 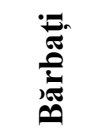 & 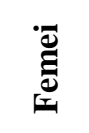 & 馬 & 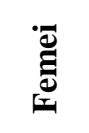 & 馬 & & 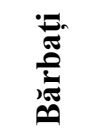 & 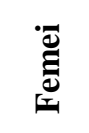 \\
\hline $0-4$ & 1 & 1 & -2 & -1 & 2 & 3 & 1 & 1 & 2 & 0 & 2 & 0 \\
\hline $5-9$ & 1 & 1 & 1 & -1 & 0 & 1 & 6 & -1 & 1 & 1 & 4 & 2 \\
\hline $10-14$ & 3 & 0 & 3 & -1 & 0 & 0 & 0 & 2 & 0 & 0 & 2 & 2 \\
\hline $15-19$ & -8 & 53 & 30 & 69 & 40 & 54 & 43 & 54 & 24 & 34 & 35 & 46 \\
\hline $20-24$ & 289 & 680 & 221 & 539 & 241 & 575 & 240 & 453 & 198 & 437 & 266 & 509 \\
\hline $25-29$ & 550 & 1025 & 607 & 1026 & 686 & 1032 & 597 & 990 & 488 & 903 & 621 & 1103 \\
\hline 30-34 & 466 & 563 & 483 & 568 & 569 & 567 & 601 & 700 & 523 & 698 & 819 & 905 \\
\hline 35-39 & 203 & 183 & 175 & 245 & 273 & 247 & 274 & 297 & 257 & 270 & 345 & 399 \\
\hline $40-49$ & 19 & 92 & 91 & 115 & 118 & 146 & 64 & 113 & -8 & 84 & 213 & 171 \\
\hline $50-54$ & 10 & 67 & 1 & 79 & 22 & 70 & -16 & 60 & -45 & 36 & 17 & 50 \\
\hline $55-59$ & -11 & 80 & 19 & 74 & 16 & 104 & -3 & 87 & -51 & 116 & -1 & 137 \\
\hline 60-64 & 20 & 70 & 10 & 77 & 9 & 73 & -3 & 48 & -3 & 59 & 14 & 75 \\
\hline 65-69 & -1 & 12 & 16 & 14 & 9 & 21 & 11 & 19 & 11 & 47 & 24 & 66 \\
\hline $70-74$ & 0 & 8 & 1 & 16 & 0 & 8 & 2 & 3 & 7 & 13 & 8 & 14 \\
\hline 75-79 & -5 & 10 & 4 & 11 & -1 & 31 & -6 & 4 & 7 & 2 & -2 & 17 \\
\hline $80-84$ & 4 & 5 & 2 & 25 & 7 & 17 & 6 & -10 & 6 & 13 & 7 & 6 \\
\hline $85+$ & -1 & 22 & 1 & 11 & 4 & 8 & 0 & 11 & 3 & 4 & -4 & 12 \\
\hline Total & 1540 & 2872 & 1663 & 2866 & 1995 & 2957 & 1817 & 2831 & 1420 & 2717 & 2370 & 3514 \\
\hline
\end{tabular}

Sursa: Calculat în baza datelor Biroului Național de Statistică

În perioada intercensitară, fluctuația numărului de nașteri și decese din mun. Chișinău a rezultat în urma mișcării valurilor demografice, iar distribuția favorabilă a numărului populației pe vârste, în decursul perioadei analizate, a asigurat un spor natural pozitiv. Dinamica numărului de nașteri a oscilat de la 7,5 mii în 2004 la circa 8,0 mii în 2010, după care înregistrând o tendință de descreștere la 6,4 mii către 2018. Numărul anual de decese din mun. Chișinău, pe durata perioadei analizate, a înregistrat unele fluctuații nesemnificative, înregistrând valori de 6,0-6,7 mii. Diferența dintre numărul de decese și nașteri a favorizat o creștere anuală a numărului populației între 0,1 mii și 1,8 mii persoane, cu o tendință de descreștere către anii recenți.

Structura populației relativ tânără reduce considerabil expunerea populației asupra riscului de deces, ceea ce se reflectă asupra numărului anual de decese; totodată, schimbările evidențiate în evoluția intensității mortalității a avut o influență nesemnificativă asupra creșterii numărului populației [6]. În același timp, populația tânără asigură un grad mai înalt de natalitate comparativ cu alte raioane (până la $25 \%$ din numărul total de nașteri), chiar dacă intensitatea fertilității în mun. Chișinău înregistrează printre cele mai joase valori în profil teritorial [4]. 


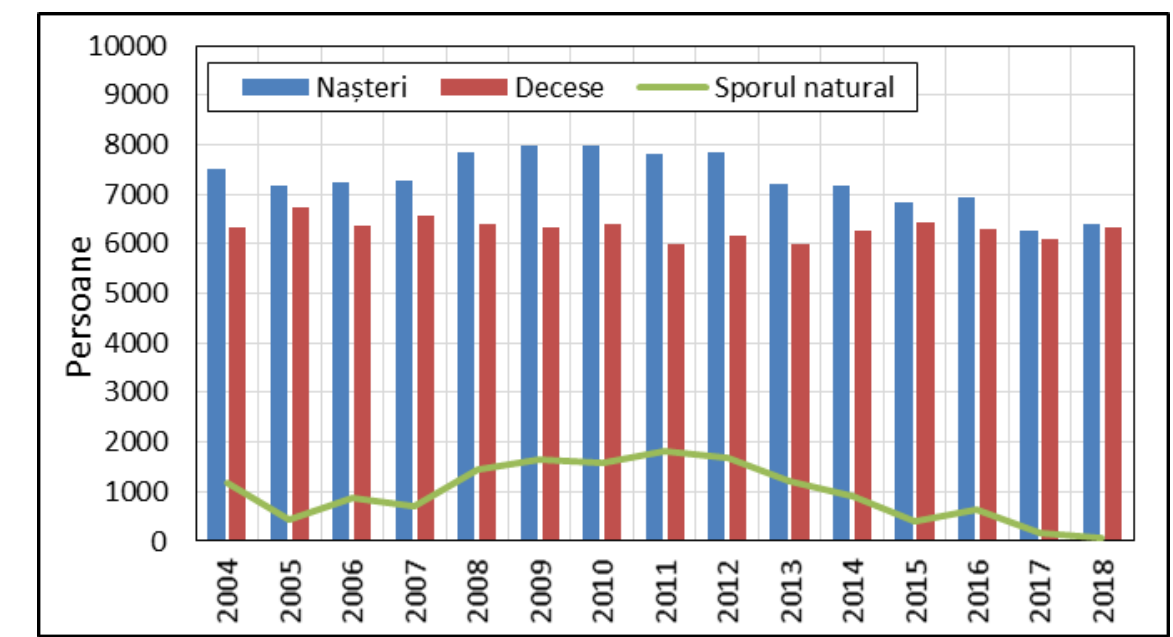

Figura 4. Evoluția mișcării naturale a populației în mun. Chișinău, anii 2004-2018

Sursa: Calculat în baza datelor Biroului Național de Statistică

\section{Concluzii}

Pe parcursul perioadei intercensitare, numărul populației din mun. Chișinău a evidențiat o creștere lentă, în mare parte aceasta se datorează migrației interne și sporului natural pozitiv. Schimbările demografice din mun. Chișinău urmează o tendință similară cu cea la nivel de republică, care remarcă o creștere a vârstei mediane - rezultat al valurilor demografice. Totodată, structura populației din mun. Chișinău este relativ tânără.

În perioada intercensitară, mișcarea naturală a populației din mun. Chișinău a asigurat un spor pozitiv cumulativ de circa 13 mii persoane. Această creștere fiind asigurată de un contingent numeric al populației de vârstă reproductivă, dar și a unui număr neînsemnat de persoane în vârstele avansate, care într-o măsură mai mare sunt supuse riscului de deces. Totodată, începând cu 2011, sporul natural înregistrează o tendință continuă de descreștere.

Comparativ cu situația privind intensitatea ascendentă a emigrației populației înregistrate la nivel de țară, rezidenții mun. Chișinău sunt într-o măsură mai mică implicați în migrația internațională. În același timp, recensămintele populației din 2004 și 2014 au evidenţiat 27,3 mii și 22,1 mii persoane aflate în afara hotarelor; locuitorii suburbiilor având un mai mare grad de implicare. Descreșterea numărului populației tinere de vârstă fertilă, având în vedere implicarea ei în migrația internațională, reduce potențialul număr anual de nașteri din mun. Chișinău.

Statutul administrativ și socioeconomic al mun. Chișinău acționează ca un pol de atracție a populației tinere și în vârsta aptă de muncă; migranții interni sunt încurajaţi spre permutarea locului de trai în favoarea învătământului superior, locurilor de muncă, serviciilor publice și infrastructurii. În contextul mun. Chișinău, migrația internă are un rol compensator al intensității emigrației populației. Creșterea numărului populației evidențiat în perioada intercensitară se datorează, în mare parte, mișcărilor migratorii interne, în perioada anilor 2011-2014 asigurând un spor mediu anual de circa 4,5 mii persoane. Sporul pozitiv al migrației interne din mun. Chișinău este asigurat de grupurile de vârstă 20-39 ani (80-95\% din sporul total). Grupurile de vârstă 0-19 ani și 40+ ani înregistrează un număr practic egal dintre sosiri și plecări, ambele înregistrând valori neînsemnate. În toți anii de referință, numărul de femei din alte raioane sosite în mun. Chișinău este cu 50-85\% mai mare decât al bărbaților din aceleași cohorte de migranți. Având în vedere aspectele metodologice, viza provizorie de reședință nu atribuie persoana populaţiei stabile.

Având în vedere un grad diferit de implicare în migrația internă dintre bărbați și femei, dar și intensitatea mortalităţii ce variază în dependență de vârstă și sex, distribuția populației pe vârste din mun. Chișinău are un caracter inegal în dependență de sex.

În context general, populația mun. Chișinău se află într-un proces de îmbătrânire, având în vedere structura actuală a populației ce evidențiază prezența unor valuri demografice. În același 
timp, în perspectivă, resursele de creștere a numărului populației din mun. Chișinău, pe seama migrației interne, sunt epuizate, ținând cont de mărimea cohortelor ce înregistrează o intensitate sporită a mișcărilor migratorii.

\section{Bibliografie}

1. Analiza situației populației în Republica Moldova. Coord. Gagauz O. Chișinău: UNFPA, CCD, 2016, 274 p.

2. Bargan N. Cu privire la evidența statistică a natalităţii. Creșterea economică în condițiile globalizării, Sesiunea științifică: "Structura Demografică și Calitatea Potențialului Uman": conferința internațională științifico-practică, 15-16 octombrie 2015. Ediţia a X-a. Institutul Național de Cercetări Economice. Chișinău, 2015, p. 142-147.

3. Biroul Național de Statistică al Republicii Moldova (BNS). Banca de date. http://www.statistica.md/pageview.php?l=en\&idc=407.

4. Grigoraș E. Monitorizarea fertilității în profil teritorial. Creșterea economică în condițiile globalizării, Sesiunea științifică: Structura Demografică și Calitatea Potențialului Uman: conferința internaţională știinţifico-practică, 15-16 octombrie 2015. Ediția a X-a. Institutul Naţional de Cercetări Economice. Chișinău, 2015, p. 189-196.

5. Informație privind mișcările migratorii interne (tabelele mg-01, mg-02). Biroul Naţional de Statistică al Republicii Moldova.

6. Pahomii I. Aspecte teritoriale ale mortalității în Republica Moldova. Creșterea economică în condițiile globalizării, Sesiunea știinţifică: Structura Demografică și Calitatea Potențialului Uman: conferința internațională științifico-practică, 15-16 octombrie 2015. Ediţia a X-a. Institutul Național de Cercetări Economice. Chișinău, 2015, p. 179-188.

7. Parlamentul Republicii Moldova. Lege privind organizarea administrativ-teritorială a Republicii Moldova: Nr. 764 din 27.12.2001. Monitorul Oficial al Republicii Moldova, 2002, Nr. 16, art. Nr: 53. http://lex.justice.md/md/312874/.

8. Rezultatele recensământului populației (2004). Biroul Național de Statistică al Republicii Moldova (BNS). http://statistica.gov.md/pageview.php?l=en\&idc=295\&.

9. Rezultatele recensământului populaţiei (2014). Biroul Național de Statistică al Republicii Moldova (BNS). http://recensamant.statistica.md/en.

10. Ștîrba V. Impactul migrației interne asupra structurii demografice în raioanele Republicii Moldova. Creșterea economică în condițiile globalizării, Sesiunea științifică: Dinamica Populației și Calitatea Potențialului Uman: conferința internațională științifico-practică, 12-13 octombrie 2017. Ediția a XI-a. Institutul Național de Cercetări Economice. Chișinău, 2017, p. 142-147.

11. Ștîrba V. Migrația internă: direcții și dimensiuni. Creșterea economică în condițiile globalizării, Sesiunea știinţifică: Dinamica Populației și Calitatea Potenţialului Uman: conferința internațională științifico-practică, 13-14 octombrie 2016. Ediția a XI-a. Institutul Național de Cercetări Economice. Chișinău, 2016, p. 60-66.

12. Табак Т. Эмиграция из Республики Молдова в постсоветский период. Демографическое развитие постсоветского пространства: сб. статей и аналитических материалов. Ред. М.Б. Денисенко, Р.В. Дмитриева, В.В. Елизаров. Москва: Экономический факультет МГУ имени М.В. Ломоносова, 2018, р. 275-296. https://www.econ.msu.ru/sys/raw.php?o=44887\&p=attachment. 